\title{
Sistem Pendukung Keputusan Menggunakan Metode Simple Additive Weighting (SAW) Untuk Program Bantuan Langsung Tunai Pasca Covid-19 Pada Desa Lais
}

\author{
Rama Andriya Saputra ${ }^{1}$, Widya Cholil* ${ }^{2}$ \\ ${ }^{1,2}$ Informatics Departement , Bina Darma University, Palembang, Indonesia \\ Email:ramaandreya@gmail.com ${ }^{1}$, widya@binadarma.ac.id ${ }^{2}$
}

\begin{abstract}
The village Fund Diret Cah Assistance (BLT-DD) is a from of financial assistance to poor families in the village sourced from the village found so that it is expected to reduce the impact COVID-19 pandemic. The village found BLT in Lais village itself does not escape several obstacles, such as the lack of community evaluation to so that delivery of the village found BLT is not on target which usually does not refer to the criteria for poor families. So the problem faced is how to determine the recipients of the village fund BLT so that is more targeted and accepted by the people who need it more. The criteria used as a reference in making decisions. This SAW calculation will later be implemented into a web using MySQL.
\end{abstract}

Keyword: Decision support system, direct cash assistance, SAW method

\section{PENDAHULUAN}

Penyakit Corona Virus Disease (COVID-19) yang ditemukan pada tahun 2019 merupakan sebuah varian virus baru yang akan mempengaruhi semua orang, negara dan bangsa. Dengan munculnya Covid-19 akan berdampak pada masyarakat, terutama masyarakat miskin dan kurang mampu. Oleh karena itu, terdapat berbagai rencana program kebijakan pemerintah untuk mengatasi perekonomian serta penanggulangan kemiskinan.

Salah satu upaya pemerintah dalam mengatasi dampak dari pandemi Covid19 ini berbentuk Bantuan Langsung Tunai Dana Desa(BLT-DD) pada tahun 2020 yang sumber anggarannya berasal dari APBN dan kemudian dikucurkan melalui Dana Desa dan diperuntukan bagi masyarakat yang terdampak covid19 baik secara langsung maupun tidak langsung yakni masyarakat yang kehilangan pekerjaan akibat pandemi.

This work is licensed under a Creative Commons Attribution 4.0 International License. 


\section{Journal of Software Engineering Ampera}

Vol. 1, No. 2, June 2021 e-ISSN: 2775-2488

https://journal-computing.org/index.php/journal-sea/index

Namun dalam implementasi pada tahap desa seringkali belum sesuai dengan harapan pemerintah pusat. Ini dikarenakan pembagian BLT Dana Desa masih sering menimbulkan persoalan kesalahpahaman tentang menafsirkan regulasi BLT Dana Desa dengan kriteria-kriteria calon penerima sehingga memunculkan konflik serta kecemburuan sosial pada masyarakat.

Pada tahap pendataan calon penerima blt dana desa dilakukan oleh relawan gugus tugas covid-19 yang ditunjuk oleh kepala desa dan kemudian dilakukan musyawarah untuk menetapkan dan memilih nama-nama kepala keluarga penerima blt dana desa yang mana masih belum efektif dan efisien sehingga dapat menyebabkan kesalahan dalam menginput data calon penerima, dengan dibuatnya sistem berbasis web ini nantinya dapat memilih calon penerima blt dana desa secara lebih effektif dan efisien yang mana dapat mempermudah dalam pemilihan nama nama kepala keluarga penerima blt dana desa.

Berdasarkan penjelasan tersebut, peneliti menggunakan sebuah sistem pendukung keputusan yang digunakan untuk mengambil sebuah keputusan dalam situasi terstruktur maupun semi terstruktur. Sehingga pihak desa bisa dapat menentukan keluarga yang layak dan tidak layak untuk menerima blt dana desa, penelitian ini menggunakan metode simple additive weighting (SAW).

\section{METODE PENELITIAN}

Dalam melakukan penelitian penulis menggunakan metode SAW pada perhitungan untuk mendapatkan perangkingan pada data menentukan Clon penerima blt dana desa pada desa lais. Dan diimplementasikan pada web menggunakan MySQL. Berikut merupakan langkah penyelesaian menggunakan metode SAW:

1. Menginput atau memasukkan kriteria nilai yang menjadi acuan dalam mengambil keputusan.

2. Memasukkan bobot atau preferensi setiap kriteria.

3. Membuat matriks keputusan sesuai kriteria.

4. Melakukan normalisasi pada matriks.

5. Menentukan reting kecocokan (bobot) setiap alternatif pada setiap kriteria. 


\section{Journal of Software Engineering Ampera}

Vol. 1, No. 2, June 2021 e-ISSN: 2775-2488

https://journal-computing.org/index.php/journal-sea/index

6. Diperoleh hasil akhir dengan melakukan proses perankingan pada setiap alternatif, sehingga didapatkan nilai terbesar yang dipilih menjadi alternatif terbaik sebagai solusi.

Adapun persamaannya adalah sebagai berikut:

$$
\mathrm{R}_{i j}= \begin{cases}\frac{\mathrm{X}_{i j}}{\operatorname{Max} \mathrm{X}_{i j}} & \text { Jika J adalah keuntungan (Benefit) } \\ \frac{\operatorname{Min}_{i} \mathrm{X}_{i j}}{\mathrm{X}_{i j}} & \text { Jika J adalah atribut biaya (Cost) }\end{cases}
$$

Keterangan setiap kriteria:

$\mathrm{R}_{i j} \quad$ : nilai rating kinerja ternormalisasi.

$\mathrm{X}_{i j} \quad$ : nilai atribut yang dimiliki dari setiap kriteria.

$\operatorname{Max} \mathrm{X}_{i j}$ : nilai terbesar dari setiap kriteria.

Min $\mathrm{X}_{i j}$ : nilai terkecil dari setiap kriteria.

Benefit :jika nilai terbesar adalah terbaik.

Cost : jika nilai terkecil adalah terbaik.

Adapun nilai referensi setiap alternatif ( $v$ ) adalah sebagai berikut:

$$
V i=\sum_{j=1}^{n} W j R i j
$$

Keterangan:

$\mathrm{Vi} \quad$ : rangking pada setiap alternatif.

Wj : nilai bobot pada setiap alternatif.

rij : nilai rating kinerja yang ternormalisasi

Nilai Vi yang lebih besar menandakan alternatif Ai lebih terpilih

\section{HASIL DAN PEMBAHASAN}

\subsection{Hasil Perhitungan}

1. Kriteria

Tahap awal dari menyelesaikan studi kasus ini adalah dengan cara menganalisa kriteria sebagai proses dasar dilakukannya seleksi. Adapun kriteria yang digunakan adalah Kondisi Rumah(C1), Kesehatan dan Pendidikan(C2), Fasilitas(C3), Penghasilan(C4). Tabungan(C5), Pengeluaran(C6). Contoh data dari kriteria tersebut adalah : 


\section{Journal of Software Engineering Ampera}

Vol. 1, No. 2, June 2021 e-ISSN: 2775-2488

https://journal-computing.org/index.php/journal-sea/index

Tabel 1. Data Kriteria

\begin{tabular}{ccc}
\hline Kriteria & Keterangan & Bobot \\
C1 & $\begin{array}{c}\text { Kondisi Rumah } \\
\text { Kesehatan dan }\end{array}$ & $25 \%$ \\
C2 & Pendidikan & $15 \%$ \\
C3 & Fasilitas & $20 \%$ \\
C4 & Penghasilan & $15 \%$ \\
C5 & Tabungan & $10 \%$ \\
C6 & Pengeluaran & $15 \%$ \\
\hline
\end{tabular}

Tabel 2. Data Rating Kecocokan

\begin{tabular}{ccccccc}
\hline \multirow{2}{*}{ Nama KK } & \multicolumn{7}{c}{ Kriteria keluarga miskin } \\
\cline { 2 - 6 } & $\begin{array}{c}\text { Kondisi } \\
\text { Rumah }\end{array}$ & $\begin{array}{c}\text { Kesehatan } \\
\text { dan } \\
\text { Pendidikan }\end{array}$ & Fasilitas & Penghasilan & Tabungan & Pengeluaran \\
\hline ZALPIHERI $\left(V_{1}\right)$ & $\mathrm{ST}$ & $\mathrm{S}$ & $\mathrm{T}$ & $\mathrm{T}$ & $\mathrm{R}$ & $\mathrm{S}$ \\
ALBAH $\left(V_{2}\right)$ & $\mathrm{T}$ & $\mathrm{S}$ & $\mathrm{T}$ & $\mathrm{T}$ & $\mathrm{R}$ & $\mathrm{T}$ \\
EDISUBANA $\left(V_{3}\right)$ & $\mathrm{ST}$ & $\mathrm{S}$ & $\mathrm{S}$ & $\mathrm{T}$ & $\mathrm{R}$ & $\mathrm{T}$ \\
ZURYAII $\left(V_{4}\right)$ & $\mathrm{T}$ & $\mathrm{R}$ & $\mathrm{S}$ & $\mathrm{T}$ & $\mathrm{R}$ & $\mathrm{S}$ \\
$\operatorname{AJIS}\left(V_{5}\right)$ & $\mathrm{ST}$ & $\mathrm{S}$ & $\mathrm{S}$ & $\mathrm{R}$ & $\mathrm{R}$ & $\mathrm{S}$ \\
IDAYULIANTI $\left(V_{6}\right)$ & $\mathrm{T}$ & $\mathrm{R}$ & $\mathrm{S}$ & $\mathrm{T}$ & $\mathrm{T}$ & $\mathrm{S}$ \\
DESI ARISANDI $\left(V_{7}\right)$ & $\mathrm{T}$ & $\mathrm{SR}$ & $\mathrm{S}$ & $\mathrm{T}$ & $\mathrm{R}$ & $\mathrm{S}$ \\
IDRUS $\left(V_{8}\right)$ & $\mathrm{S}$ & $\mathrm{R}$ & $\mathrm{S}$ & $\mathrm{T}$ & $\mathrm{T}$ & $\mathrm{T}$ \\
$\operatorname{RASID}\left(V_{9}\right)$ & $\mathrm{T}$ & $\mathrm{R}$ & $\mathrm{S}$ & $\mathrm{T}$ & $\mathrm{T}$ & $\mathrm{R}$ \\
MARYANTO $\left(V_{10}\right)$ & $\mathrm{T}$ & $\mathrm{R}$ & $\mathrm{R}$ & $\mathrm{T}$ & $\mathrm{R}$ & $\mathrm{S}$ \\
\hline
\end{tabular}

\section{Pembobotan Kriteria}

Dalam menentukan pemilihan calon penerima bantuan langsung tunai dana desa menggunakan metode SAW, maka ditentukan terlebih dahulu nilai awal setiap kriteria, pada penilaian bilangan fuzzy terdiri dari, Sangat Rendah(SR), Rendah (R), Sedang(S), Tinggi(T),Sangat Tinggi(ST), Seperti pada gambar berikut.

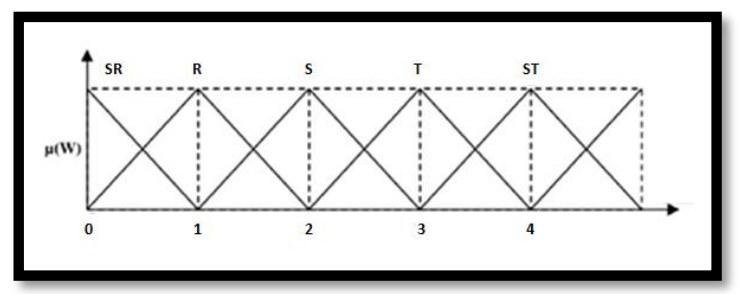

Gambar 1 Diagram bilangan Fuzzy untuk nilai kriteria 


\section{Journal of Software Engineering Ampera}

Vol. 1, No. 2, June 2021 e-ISSN: 2775-2488

https://journal-computing.org/index.php/journal-sea/index

Dari gambar diatas, bilangan-bilangan fuzzy dapat dikonversikan ke bilangan crisp. Lebih jelasnya data bilangan fuzzy dapat dilihat pada tabel dibawah ini.

Tabel 3. Pembobotan Kriteria

\begin{tabular}{cc}
\hline BOBOT & NILAI \\
Sangat tinggi (ST) & 4 \\
Tinggi (T) & 3 \\
Sedang (S) & 2 \\
Rendah (R) & 1 \\
Sangat Rendah (SR) & 0 \\
\hline
\end{tabular}

Setelah melakukan pembobotan pada data tersebut, maka dapat di lihat kecocokan pada masing-masing alternatif terhadap kriteria yang bisa dilihat pada tabel berikut.

Tabel 4. Rating Kecocokan

\begin{tabular}{|c|c|c|c|c|c|c|c|}
\hline \multirow[b]{2}{*}{ No } & \multirow[b]{2}{*}{ Nama KK } & \multicolumn{6}{|c|}{ Kriteria keluarga miskin } \\
\hline & & $\begin{array}{l}\text { Kondisi } \\
\text { Rumah }\end{array}$ & $\begin{array}{l}\text { Kesehatan } \\
\text { dan } \\
\text { Pendidikan }\end{array}$ & Fasilitas & Penghasilan & Tabungan & Pengeluaran \\
\hline 1 & ZALPIHERI $\left(V_{1}\right)$ & 4 & 2 & 3 & 3 & 1 & 2 \\
\hline 2 & $\operatorname{ALBAH}\left(V_{2}\right)$ & 3 & 2 & 3 & 3 & 1 & 3 \\
\hline 3 & $\operatorname{EDISUBANA}\left(V_{3}\right)$ & 4 & 2 & 2 & 3 & 1 & 3 \\
\hline 4 & ZURYATI $\left(V_{4}\right)$ & 3 & 1 & 2 & 3 & 1 & 2 \\
\hline 5 & $\operatorname{AJIS}\left(V_{5}\right)$ & 4 & 2 & 2 & 1 & 1 & 2 \\
\hline 6 & IDAYULIANTI $\left(V_{6}\right)$ & 3 & 1 & 2 & 3 & 3 & 2 \\
\hline 7 & DESI ARISANDI $\left(V_{7}\right)$ & 3 & 0 & 2 & 3 & 1 & 2 \\
\hline 8 & $\operatorname{IDRUS}\left(V_{8}\right)$ & 2 & 1 & 2 & 3 & 3 & 3 \\
\hline 9 & $\operatorname{RASID}\left(V_{9}\right)$ & 3 & 1 & 2 & 3 & 3 & 1 \\
\hline 10 & MARYANTO $\left(V_{10}\right)$ & 3 & 1 & 1 & 3 & 1 & 2 \\
\hline
\end{tabular}

Berikut merupakan langkah penyelesaian metode SAW :

a. Matriks Keputusan $X$

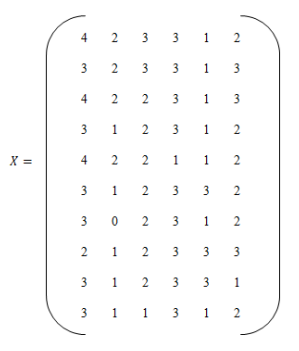




\section{Journal of Software Engineering Ampera}

Vol. 1, No. 2, June 2021 e-ISSN: 2775-2488

https://journal-computing.org/index.php/journal-sea/index

b. Normalisasi matriks $X$ dengan rumus $r_{i j}=\frac{x_{i j}}{\max _{i j}}$

Normalisasi matriks kriteria alternatif $V_{1}$ ZALPIHERI

$$
\begin{aligned}
& r_{11}=\frac{4}{\max (4,3,4,3,4,3,3,2,3,3)}=1 \\
& r_{12}=\frac{2}{\max (2,2,2,1,2,1,0,1,1,1)}=1 \\
& r_{13}=\frac{3}{\max (3,3,2,2,2,2,2,2,2,1)}=1 \\
& r_{14}=\frac{3}{\max (3,3,3,3,1,3,3,3,3,3)}=1 \\
& r_{15}=\frac{1}{\max (1,1,1,1,1,3,1,3,3,1)}=0,33 \\
& r_{16}=\frac{2}{\max (2,3,3,2,2,2,2,3,1,2)}=0,67
\end{aligned}
$$

Normalisasi matriks kriteria alternatif $V_{2} \mathrm{ALBAH}$

$$
\begin{aligned}
& r_{21}=\frac{3}{\max (4,3,4,3,4,3,3,2,3,3)}=0,75 \\
& r_{22}=\frac{2}{\max (2,2,2,1,2,1,0,1,1,1)}=1 \\
& r_{23}=\frac{3}{\max (3,3,2,2,2,2,2,2,2,1)}=1 \\
& r_{24}=\frac{3}{\max (3,3,3,3,1,3,3,3,3,3)}=1 \\
& r_{25}=\frac{1}{\max (1,1,1,1,1,3,1,3,3,1)}=0,33 \\
& r_{26}=\frac{3}{\max (2,3,3,2,2,2,2,3,1,2)}=1
\end{aligned}
$$

Normalisasi matriks kriteria alternatif $V_{3}$ EDISUBANA

$$
\begin{aligned}
& r_{31}=\frac{4}{\max (4,3,4,3,4,3,3,2,3,3)}=1 \\
& r_{32}=\frac{2}{\max (2,2,2,1,2,1,0,1,1,1)}=1 \\
& r_{33}=\frac{2}{\max (3,3,2,2,2,2,2,2,2,1)}=0,67 \\
& r_{34}=\frac{3}{\max (3,3,3,3,1,3,3,3,3,3)}=1 \\
& r_{35}=\frac{1}{\max (1,1,1,1,1,3,1,3,3,1)}=0,33 \\
& r_{36}=\frac{3}{\max (2,3,3,2,2,2,2,3,1,2)}=1
\end{aligned}
$$

Normalisasi matriks kriteria alternatif $V_{4}$ ZURYATI

$$
\begin{aligned}
& r_{41}=\frac{3}{\max (4,3,4,3,4,3,3,2,3,3)}=0,75 \\
& r_{42}=\frac{1}{\max (2,2,2,1,2,1,0,1,1,1)}=0,5 \\
& r_{43}=\frac{2}{\max (3,3,2,2,2,2,2,2,2,1)}=0,67 \\
& r_{44}=\frac{3}{\max (3,3,3,3,1,3,3,3,3,3)}=1
\end{aligned}
$$




\section{Journal of Software Engineering Ampera}

Vol. 1, No. 2, June 2021 e-ISSN: 2775-2488

https://journal-computing.org/index.php/journal-sea/index

$$
\begin{aligned}
& r_{45}=\frac{1}{\max (1,1,1,1,1,3,1,3,3,1)}=0,33 \\
& r_{46}=\frac{2}{\max (2,3,3,2,2,2,2,3,1,2)}=0,67
\end{aligned}
$$

Normalisasi matriks kriteria alternatif $V_{5}$ AJIS

$$
\begin{aligned}
& r_{51}=\frac{4}{\max (4,3,4,3,4,3,3,2,3,3)}=1 \\
& r_{52}=\frac{2}{\max (2,2,2,1,2,1,0,1,1,1)}=1 \\
& r_{53}=\frac{2}{\max (3,3,2,2,2,2,2,2,2,1)}=0,67 \\
& r_{54}=\frac{1}{\max (3,3,3,3,1,3,3,3,3,3)}=0,33 \\
& r_{55}=\frac{1}{\max (1,1,1,1,1,3,1,3,3,1)}=0.33 \\
& r_{56}=\frac{2}{\max (2,3,3,2,2,2,2,3,1,2)}=0.67
\end{aligned}
$$

Berdasarkan perhitungan di atas, dari hasil normalisasi (rij) membentuk matriks ternormalisasi R :

$$
R=\left(\begin{array}{llllll}
1 & 1 & 1 & 1 & 0,33 & 0,67 \\
0,75 & 1 & 1 & 1 & 0,33 & 1 \\
1 & 1 & 0.67 & 1 & 0,33 & 1 \\
0.75 & 0,5 & 0,67 & 1 & 0,33 & 0,67 \\
1 & 1 & 0,67 & 0,33 & 0,33 & 0,67 \\
0,75 & 0,5 & 0,67 & 1 & 1 & 0,67 \\
0,75 & 0 & 0,67 & 1 & 0,33 & 0,67 \\
1 & 0,5 & 0,67 & 1 & 0,33 & 1 \\
0,75 & 0,5 & 0,67 & 1 & 1 & 0,33 \\
0,75 & 0,5 & 0,33 & 1 & 0,33 & 0,67
\end{array}\right.
$$

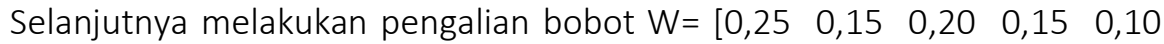
$0,15]$ dengan rumus $V=W \times R$

$$
\begin{aligned}
& V_{1}=(0,25 \times 1)+(0,15 \times 1)+(0,20 \times 1)+(0,15 \times 1)+(0,10 \times 0,33)+(0,15 \times 0,67)=0,88 \\
& V_{2}=(0,25 \times 0,75)+(0,15 \times 1)+(0,20 \times 1)+(0,15 \times 1)+(0,10 \times 0,33)+(0,15 \times 1)=0,87 \\
& V_{3}=(0,25 \times 1)+(0,15 \times 1)+(0,20 \times 0,67)+(0,15 \times 1)+(0,10 \times 0,33)+(0,15 \times 1)=0,87 \\
& V_{4}=(0,25 \times 0,75)+(0,15 \times 0,5)+(0,20 \times 0,67)+(0,15 \times 1)+(0,10 \times 0,33)+(0,15 \times 0,67)=0,68 \\
& V_{5}=(0,25 \times 1)+(0,15 \times 1)+(0,20 \times 0,67)+(0,15 \times 0,33)+(0,10 \times 0,33)+(0,15 \times 0,67)=0,72 \\
& V_{6}=(0,25 \times 0.75)+(0,15 \times 0,5)+(0,20 \times 0,67)+(0,15 \times 1)+(0,10 \times 1)+(0,15 \times 0,67)=0,75 \\
& V_{7}=(0,25 \times 0,75)+(0,15 \times 0)+(0,20 \times 0,67)+(0,15 \times 1)+(0,10 \times 0,33)+(0,15 \times 0,67)=0,61 \\
& V_{8}=(0,25 \times 1)+(0,15 \times 0,5)+(0,20 \times 0,67)+(0,15 \times 1)+(0,10 \times 0,33)+(0,15 \times 1)=0,73 \\
& V_{9}=(0,25 \times 0,75)+(0,15 \times 0,5)+(0,20 \times 0,67)+(0,15 \times 1)+(0,10 \times 1)+(0,15 \times 0,33)=0,7 \\
& V_{10}=(0,25 \times 0,75)+(0,15 \times 0,5)+(0,20 \times 0,33)+(0,15 \times 1)+(0,10 \times 0,33)+(0,15 \times 0,67)=0,61
\end{aligned}
$$

Untuk menentukan batas layak dan tidak layak dilakukan dengan cara; $\frac{\text { nilaibobotkriteriatertinggi }(M A X)}{\text { jumlahkriteria }}=\frac{4}{6}=0,66$ 


\section{Journal of Software Engineering Ampera}

Vol. 1, No. 2, June 2021 e-ISSN: 2775-2488

https://journal-computing.org/index.php/journal-sea/index

Jadi untuk nilai 0-0,66 dinyatakan tidak layak, dan untuk nilai 0,67-1 dinyatakan layak. Maka dari hasil perhitungan di atas di dapat untuk nilai yang layak yaknipada variabel :

Tabel 5. Perangkingan Alternatif hasil perhitungan SAW

\begin{tabular}{ccc}
\hline Nama KK & Perhitungan SAW & Layak / tidak layak \\
\hline ZALPIHERI $\left(V_{1}\right)$ & 0,88 & Layak \\
$\operatorname{ALBAH}\left(V_{2}\right)$ & 0,87 & Layak \\
$\operatorname{EDISUBANA}\left(V_{3}\right)$ & 0,68 & Layak \\
$\operatorname{ZURYATI}\left(V_{4}\right)$ & 0,72 & Layak \\
$\operatorname{AJIS}\left(V_{5}\right)$ & 0,75 & Layak \\
IDAYULIANTI $\left(V_{6}\right)$ & 0,75 & Layak \\
$\operatorname{DESI}$ ARISANDI $\left(V_{7}\right)$ & 0,61 & Tidak layak \\
$\operatorname{IDRUS}\left(V_{8}\right)$ & 0,73 & Layak \\
$\operatorname{RASID}\left(V_{9}\right)$ & 0,7 & Layak \\
$\operatorname{MARYANTO}\left(V_{10}\right)$ & 0,61 & Tidak layak \\
\hline
\end{tabular}

Dari tabel 5 Maka di dapat ranking kelayakan calon penerima bantuan langsung tunai berdasarkan nama kepala keluarga yang memiliki nilai perhitungan SAW dari rentan nilai 0,67-1 yakni pada alternatif

$\begin{array}{ll}\text { ZALPIHERI }\left(V_{1}\right) & \text { dengan nilai }=0,88 \\ \operatorname{ALBAH}\left(V_{2}\right) & \text { dengan nilai }=0,87 \\ \operatorname{EDISUBANA}\left(V_{3}\right) & \text { dengan nilai }=0,68 \\ \operatorname{ZURYATI}\left(V_{4}\right) & \text { dengan nilai }=0,72 \\ \operatorname{AJIS}\left(V_{5}\right) & \text { dengan nilai }=0,75 \\ \operatorname{IDAYULIANTI}\left(V_{6}\right) & \text { dengan nilai }=0,75 \\ \operatorname{IDRUS}\left(V_{8}\right) & \text { dengan nilai }=0,73 \\ \operatorname{RASID}\left(V_{9}\right) & \text { dengan nilai }=0,7\end{array}$

\subsection{Implementasi}

Berikut merupakan pembahasan dari hasil uji coba pada web dan tampilan dari setiap menu-menu yang ada pada sistem pemilihan calon penerima blt dana desa pada desa lais.

\subsubsection{Tampilan Halaman Utama}

Halaman ini merupakan tamoilan utama pada pengguna, pada halaman ini bisa diakses oleh siapa saja termasuk masyrakat, karena bersifat umum. User 


\section{Journal of Software Engineering Ampera}

Vol. 1, No. 2, June 2021 e-ISSN: 2775-2488

https://journal-computing.org/index.php/journal-sea/index

dapat melakukan lihat menu dashbord, nama-nama KK yang menerima blt, dan menu login yang hanya bisa di akses untuk admin.

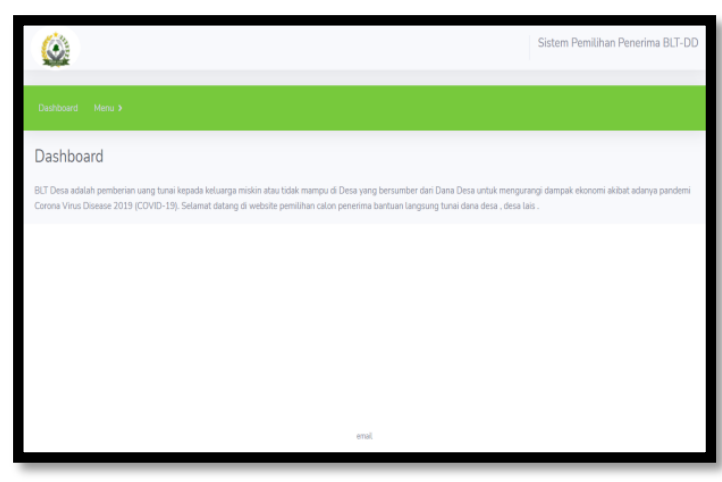

Gambar 2. Halaman Utama

\subsubsection{Tampilan Halaman Data Penerima Blt}

Halaman ini merupakan halaman untuk memberikan informasi data kepala keluarga penerima bantuan langsung tunai. Data ini didapatkan secara otomatis pada proses perhitungan data pada admin.

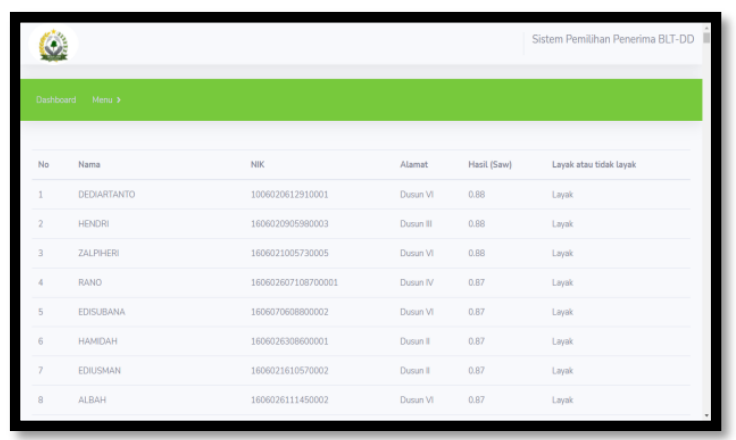

Gambar 3 Data Penerima Blt

\subsubsection{Tampilan Halaman Login Admin}

Halaman ini merupakan halaman yang berfungsi untuk tempat admin login dihalaman admin, pada halaman admin ini terdapat menu yang akan mengelolah untuk sistem pemilihan calon penerima bantuan langusung tunai menggunakan metode SAW. 


\section{Journal of Software Engineering Ampera}

Vol. 1, No. 2, June 2021 e-ISSN: 2775-2488

https://journal-computing.org/index.php/journal-sea/index

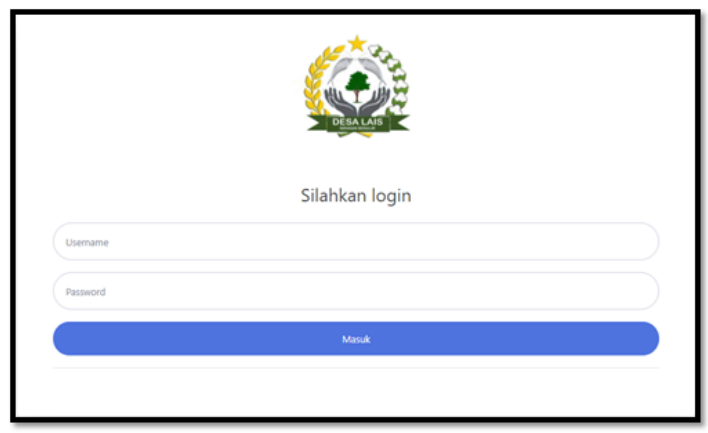

Gambar 4 Halaman Login Admin

\subsubsection{Tampilan Halaman Data}

Halaman ini menampilkan halaman data calon penerima bantuan langusng tunai dana desa.

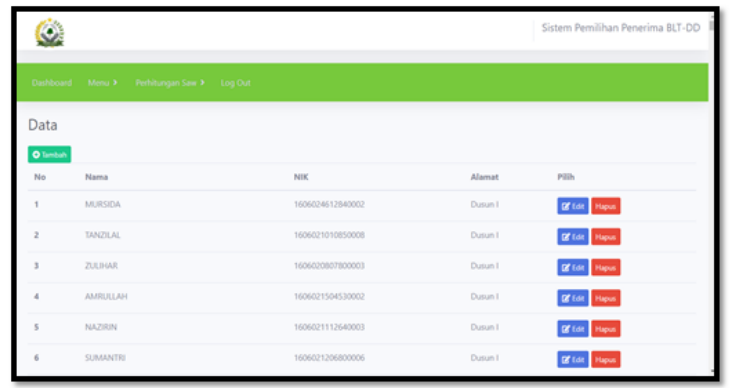

Gambar 5 Halaman Data

\subsubsection{Tampilan Tambah Data}

Ini merupakan halaman untuk menambah data baru calon penerima bantuan langsung tunai dana desa.

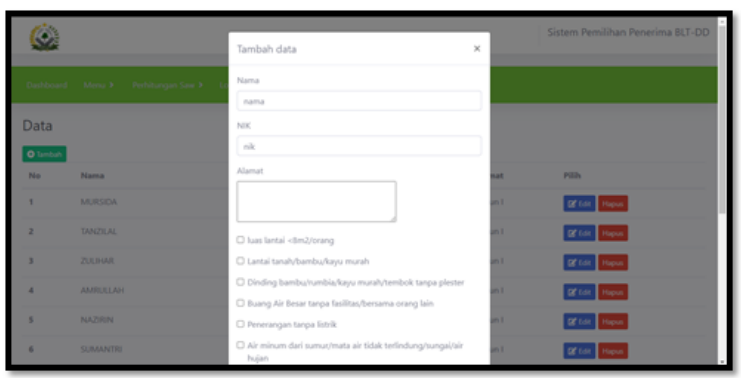

Gambar 6 Halaman Tampilan Tambah Data 


\section{Journal of Software Engineering Ampera}

Vol. 1, No. 2, June 2021 e-ISSN: 2775-2488

https://journal-computing.org/index.php/journal-sea/index

\subsubsection{Tampilan Halaman Kriteria Awal}

Halaman ini merupakan halaman yang menampilkan kriteria penerima bantuan langsung tunai.

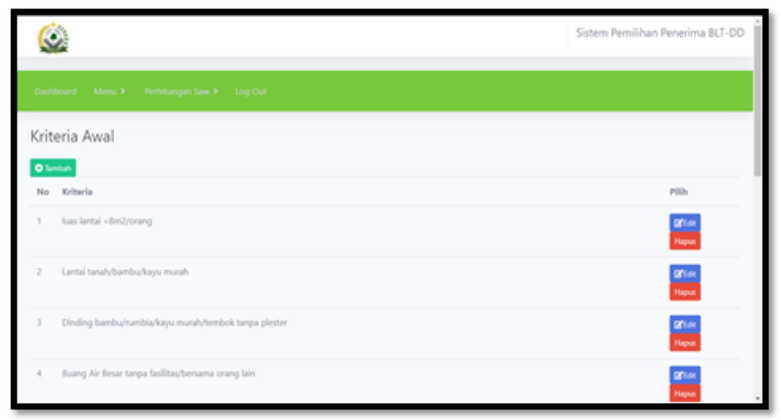

Gambar 8 Halaman Kriteria Awal

\subsubsection{Tampilan Halaman Tambah Kriteria Awal}

Halaman ini merupkan tampilan halaman untuk menambah kriteria jika suatu waktu nanti terdapat kriteria baru dalam memilih calon penerima bantuan langsung tunai.

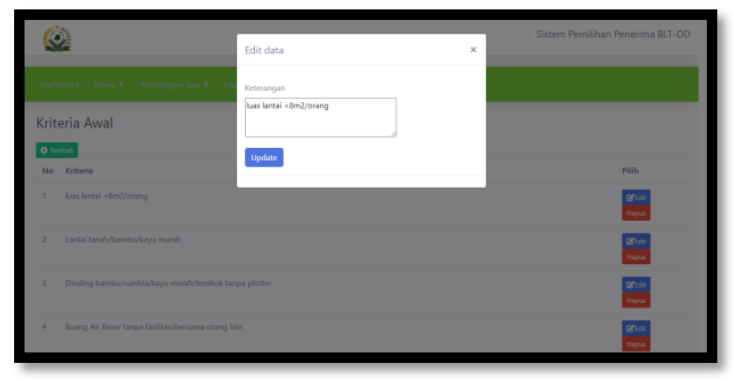

Gambar 9 Halaman Tambah Kriteria Awal

\subsubsection{Tampilan Halaman Normalisasi}

Halaman ini merupakan halaman untuk menampilkan bobot parameter yang digunakan di perhitungan SAW dalam pemilihan calon penerima BLT. 


\section{Journal of Software Engineering Ampera}

Vol. 1, No. 2, June 2021 e-ISSN: 2775-2488

https://journal-computing.org/index.php/journal-sea/index

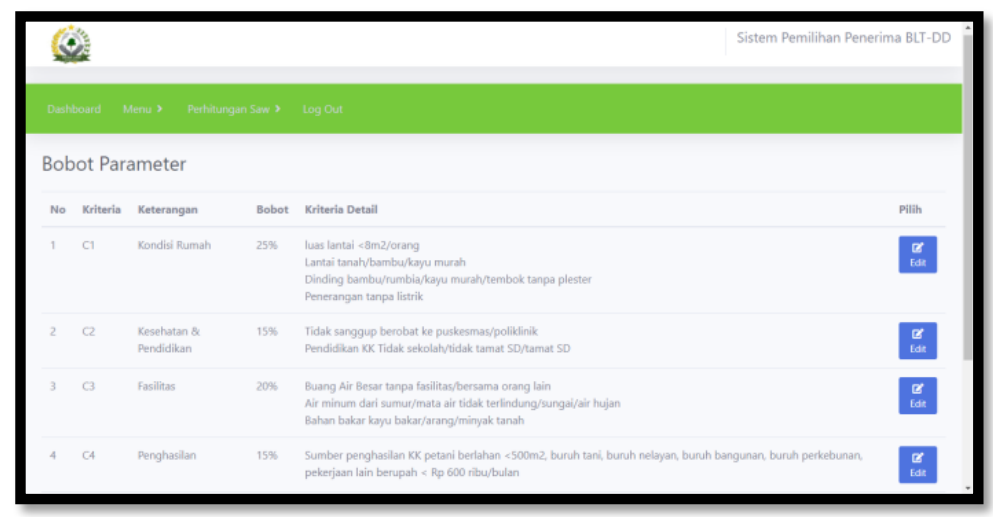

Gambar 10. Halaman Bobot Parameter

\subsubsection{Tampilan Halaman Edit Bobot Parameter}

Ini merupakan halaman untuk mengedit bobot parameter yang berfungsi untuk mengubah atau mengedit bobot parameter jika ada perubahan yang diperlukan.

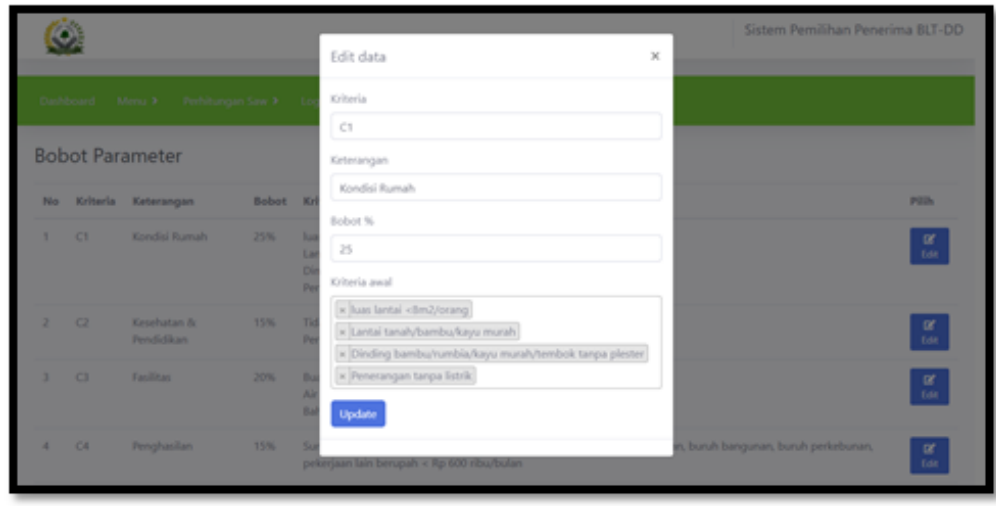

Gambar 11 Halaman Edit Bobot Parameter

\subsubsection{Tampilan Halaman Bobot Kriteria}

Halaman ini merupakan tampilan halaman pada bobot kriteria calon penerima bantuan langsung tunai. 


\section{Journal of Software Engineering Ampera}

Vol. 1, No. 2, June 2021 e-ISSN: 2775-2488

https://journal-computing.org/index.php/journal-sea/index

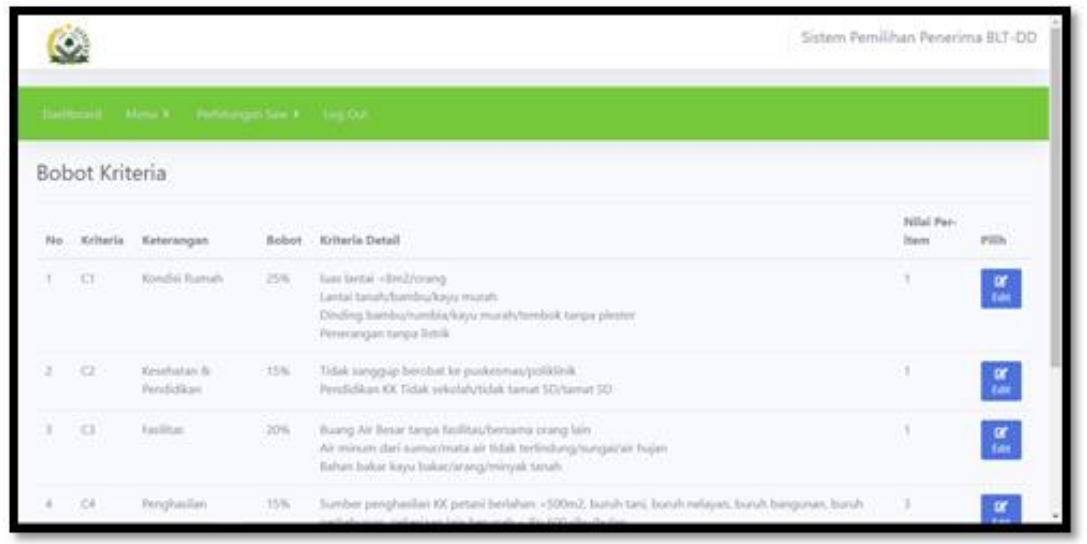

Gambar 12 Halaman Bobot Kriteria

\subsubsection{Tampilan Halaman Edit Bobot Kriteria}

Halaman ini merupakan tampilan halaman untuk mengedit atau merubah nilai peritem pada bobot kriteria jika nanti perlu diperbarui.

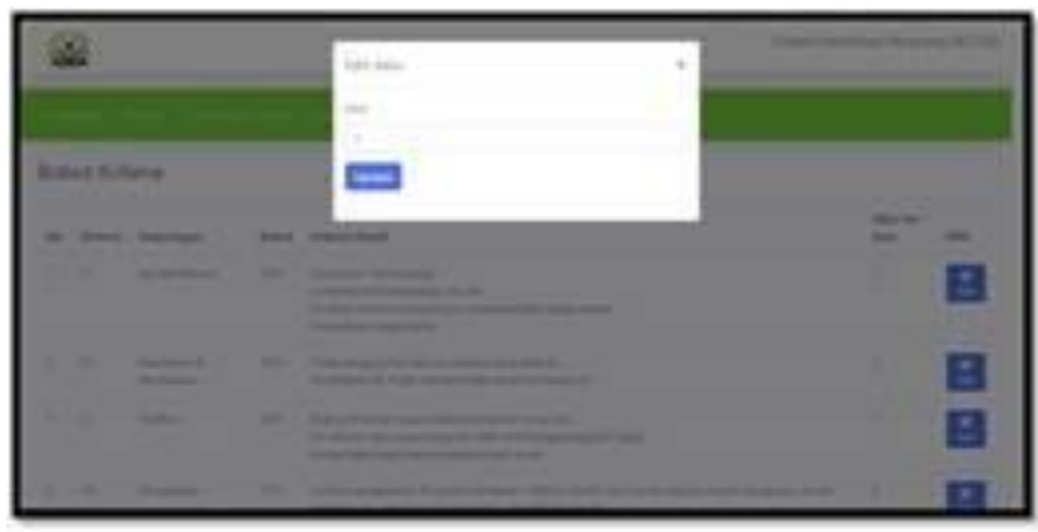

Gambar 13 Halaman Edit Bobot Kriteria

\subsubsection{TampilaN Halaman Matriks Keputusan}

Halaman ini merupakan tampilan halaman perhitungan pertama pada metode SAW yakni matriks keputusan. 


\section{Journal of Software Engineering Ampera}

Vol. 1, No. 2, June 2021 e-ISSN: 2775-2488

https://journal-computing.org/index.php/journal-sea/index

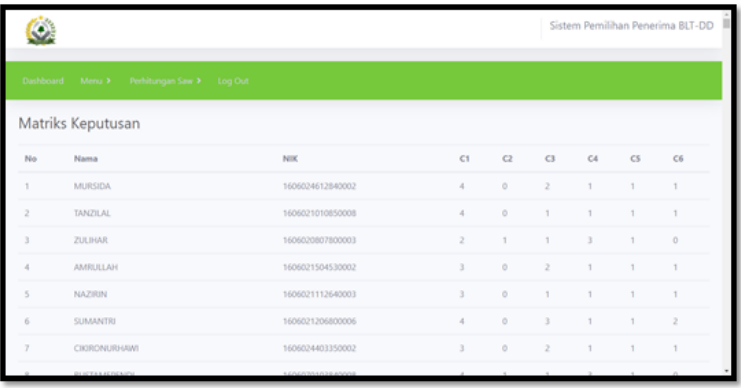

Gambar 14 Halaman Matriks Keputusan

\subsubsection{Tampilan Halaman Matriks Normalisasi}

Halaman ini merupakan tampilan halaman matriks hasil normalisasi pada data dengan metode SAW.

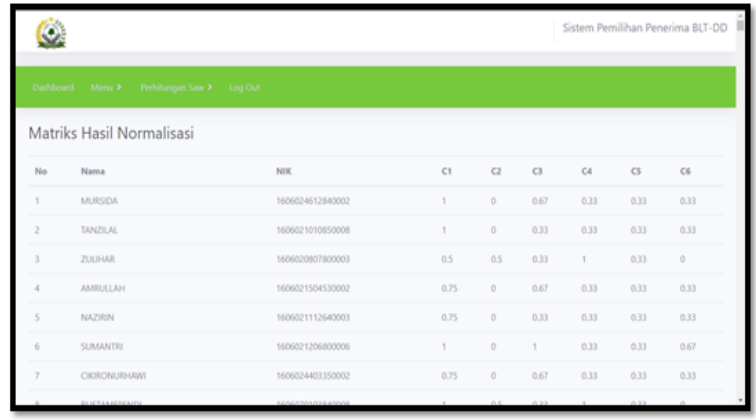

Gambar 15 Halaman Matriks Normalisasi

\subsubsection{Tampilan Halaman Peringkat}

Halaman ini merupalan tampilan halaman peringkat penerima bantuan langsung tunai sesuai dengan perhitungan metode SAW.

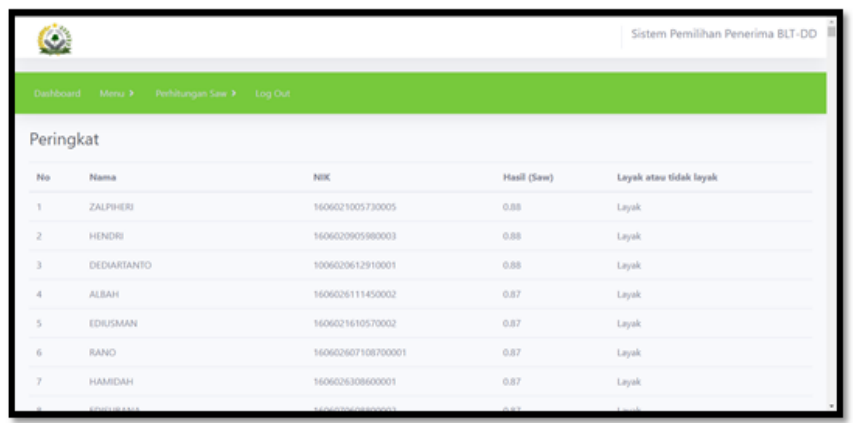

Gambar 16 Halaman Peringkat

92 | Sistem Pendukung Keputusan Menggunakan Metode Simple Additive ..... 


\section{Journal of Software Engineering Ampera}

Vol. 1, No. 2, June 2021 e-ISSN: 2775-2488

https://journal-computing.org/index.php/journal-sea/index

\section{KESIMPULAN}

Sebagai akhir dari penunulisan skripsi ini, adapun kesimpulan atas tulisan yang telah penulis buat pada bab-bab sebelumnya sebagai berikut.

1. Hasil dari tulisan skripsi ini yaitu menghasilkan rancangan dan sebuah metode perhitungan berbasis web yang dibangun agar dapat mentukan calon penerima bantuan lansung tunai yang diguanakan pada kantor kepadala desa Lais.

2. Dengan adanya sistem ini dapat mempermudah menentukan penerima yang layak untuk bantuan langsung tunai berdasarkan peringkat.

3. Pembuktian kebenaran sistem dibuktikan dengan melakukan perhitungan manual metode SAW dalam bab 3. Kemudian hasil yang diperoleh sistem memiliki kesamaan dengan perhitungan manual.

\section{DAFTAR PUSTAKA}

[1] Aeni Hidayah, N., \& Fetrina, E. (2017). RANCANG BANGUN SISTEM PENDUKUNG KEPUTUSAN KENAIKAN JABATAN PEGAWAI DENGAN METODE PROFILE MATCHING (Studi Kasus: Kementerian Agama Kantor Wilayah DKI Jakarta). Studia Informatika: Jurnal Sistem Informasi, 10(2), 127-134.

[2] Astuti, R., \& Mukaromah, U. (2021). Model Manajemen Sistem Pendukung Keputusan Metode Simple Additive Weighting untuk Program Bantuan Langsung Tunai di Desa Luwungbata. Media Informatika, 19(3), 88-97. https://doi.org/10.37595/mediainfo.v19i3.47

[3] Cholil, W., Wahyudi, Y., \& Wardani, K. R. (2013). ANALISIS KINERJA KONEKSI INTERNET PENDUKUNG SISTEM MONITORING BERBASIS WEB (CCTV ONLINE). Prosiding SeNAIK, 428-433.

[4] EFAN, S., Widya, C., \& Nia, O. (2020). RANCANG BANGUN SISTEM INFORMASI INVENTORY MENGGUNAKAN METODE SDLC (SYSTEM DEVELOPMENT LIFE CYCLE) PADA PT. SATRIA JAYA PRIMA (Doctoral dissertation, Universitas Bina Darma).

[5] Kementerian Perencanaan Pembangunan Nasional. (2020). Panduan Pendataan Bantuan Langsung Tunai - BLT Dana Desa. E-Book, 1-26.

[6] Novendri, M. S., Saputra, A., \& Firman, C. E. (2019). Aplikasi Inventaris Barang Pada MTS Nurul Islam Dumai Menggunakan PHP Dan MySQL. Lentera Dumai, 10(2), 46-57. 


\section{Journal of Software Engineering Ampera}

Vol. 1, No. 2, June 2021 e-ISSN: 2775-2488

https://journal-computing.org/index.php/journal-sea/index

[7] Puteri, M. P., \& Effendi, H. (2018). Implementasi Metode RAD Pada Website Service Guide "Tour Waterfall South Sumatera." Jurnal Sisfokom (Sistem Informasi Dan Komputer), 7(2), 130. https://doi.org/10.32736/sisfokom.v7i2.570

[8] Setiya Setiya Nugroho, F. T. W. N. (2016). Penerapan Metode Madm-Saw Dalam Penentuan Produk. Simetris, 7(1), 163-168.

[9] Sukur, moch halim. (2020). Penanganan Pelayanan Kesehatan Di Masa Pandemi Covid-19 Dalam Perspektif Hukum Kesehatan. Journal Inicio Legis Volume 1 Nomor 1 Oktober 2020, 1, 1-17.

[10] Suyanto, S., Cholil, W., \& Chandra, I. (2014). PENERAPAN METODE AHP PADA SISTEM PENUNJANG KEPUTUSAN KELAYAKAN PEMBERIAN KREDIT. SEMNASTEKNOMEDIA ONLINE, 2(1), 2-04. 